\title{
Biofilms formed on humic substances: Response to flow conditions and carbon concentrations
}

\author{
A.L. Rodrigues ${ }^{a}$, M.A. Pereira ${ }^{a}$, P. Janknecht ${ }^{b}$, A.G. Brito ${ }^{a}$, R. Nogueira ${ }^{a, *}$ \\ ${ }^{a}$ IBB - Institute for Biotechnology and Bioengineering, Centre of Biological Engineering, University of Minho, Campus de Gualtar, 4710-057 Braga, Portugal \\ ${ }^{\mathrm{b}}$ Stadtwerke Düsseldorf AG - Wasserwerke, Himmelgeister Landstrasse 1, 40589 Düsseldorf, Germany
}

\section{A R T I C L E I N F O}

\section{Article history:}

Received 4 January 2010

Received in revised form 27 March 2010

Accepted 30 March 2010

Available online 21 April 2010

\section{Keywords:}

Humic substances

Biofilm

Flow velocity

Community composition

DGGE

\begin{abstract}
A B S T R A C T
Stream biofilms are exposed to dynamic conditions of flow velocity and organic carbon availability. Thus, the aim of this study was to investigate the response of biofilms formed with and without humic substances (HSs) to an increase in flow velocity $\left(0.04-0.10 \mathrm{~m} \mathrm{~s}^{-1}\right)$ and HSs concentration $(9.7 \pm 1.0$ to $19.8 \pm 0.4 \mathrm{mg} \mathrm{L}^{-1} \mathrm{C}$ ). The highest amount of biofilm, measured as volatile suspended solids and total countable cells, was observed at $0.10 \mathrm{~m} \mathrm{~s}^{-1}$ without HSs. The bacterial community composition of the biofilm with HSs was characterized by sequences with high similarities ( $\geqslant 97 \%$ ) to the genus Dokdonella and to the genera Comamonas, Cupriavidus and, Ralstonia. Sequences retrieved from the biofilm without HSs presented high similarities ( $\geqslant 97 \%$ ) to the genus Sphingomonas and the genus Nitrosospira. Experimental results suggested that the presence of HSs under different concentrations and flow velocities did not significantly enhance the cell density of biofilms but influenced its microbial composition.
\end{abstract}

(c) 2010 Elsevier Ltd. All rights reserved.

\section{Introduction}

Most bacteria in streams and rivers live in biofilms attached to surfaces which contribute to carbon and nutrients cycling (Lawrence and Neu, 2003). Biofilm formation is controlled by an array of coupled physical, chemical, and biological processes (Bryers and Characklis, 1982). Previous experiments demonstrated that hydrodynamic conditions and biodegradable organic matter concentration are two of the most important factors that affect biofilm growth and detachment in natural systems (Battin et al., 2003; Besemer et al., 2007). Stream biofilms are exposed to a wide range of flow velocities and carbon concentrations. The range of flow velocities described in literature varies between 0.019 and $0.29 \mathrm{~m} \mathrm{~s}^{-1}$ (Tank and Dodds, 2003). In oligotrophic surface waters, dissolved organic carbon (DOC) concentrations reported are between 1 and $60 \mathrm{mg} \mathrm{L}^{-1}$ (Beckett, 1990).

Natural organic matter (NOM) present in streams and rivers is mainly formed by humic substances (HSs). They are complex organic molecules containing various functional groups (e.g. carboxylic and phenolic) and, randomly condensed aromatic rings (Lin et al., 2001). HSs, particularly humic and fulvic acids, make up about $75 \%$ of the DOC in stream waters (Wetzel, 2001). The question as to whether or not HSs are taken up by organisms has been

\footnotetext{
* Corresponding author. Address: University of Minho - DEB, Campus de Gualtar 4710-057 Braga, Portugal. Tel.: +351 964208 581; fax: +351 253678986.

E-mail addresses: alexandrina@deb.uminho.pt (A.L. Rodrigues), regina@deb. uminho.pt (R. Nogueira).
}

argued intensely in the literature. Although they have commonly been considered recalcitrant, Kim et al. (2006) recently reported that humic substances substantially contribute to stream biodegradable DOC. The main DOC transformations take place in the streambed (Lawrence and Neu, 2003).

Phylogenetic affiliation of bacteria in biofilms has been investigated by molecular 16S rRNA gene-targeting techniques. Microbial community fingerprinting by denaturing gradient gel electrophoresis (DGGE), cloning and, sequencing analysis is shown to be a suitable cultivation-independent technique for analysis of complex microbial communities (Amann et al., 1995). Typical groups of bacteria that are present in freshwater biofilms are affiliated to alphaProteobacteria, beta-Proteobacteria and gamma-Proteobacteria. Generally, alpha-Proteobacteria dominate natural freshwater systems that are oligo- or mesotrophic (Pinhassi and Berman, 2003; Olapade and Leff, 2005). Beta-Proteobacteria have been reported to be the most abundant bacterial group in freshwater ecosystems and are also considered a diverse and opportunistic group present in abundance in a variety of conditions, namely in polluted rivers (Brümmer et al., 2003). The majority of freshwater ammonia-oxidizing bacteria are also beta-Proteobacteria (Kowalchuk and Stephen, 2001). Gamma-Proteobacteria may be an opportunistic group under highnutrient conditions, presenting a lower activity in oligotrophic systems (Pinhassi and Berman, 2003). They also contain some of the common bacteria which are known as pollutant degraders (Fang et al., 2007) and some of the main aquatic denitrifiers.

Biofilms proliferate in streams and rivers (Battin et al., 2003), as well as in treatment facilities (Peterson, 2008) to prepare drinking 
water (e.g. granular-media filters). A considerable challenge is envolved in the development of environmental technologies that exploit natural biofilms (biofilms upstream of the water plant) to increase water quality prior to treatment. The impact of such a measure would be the reduction of the demand of chlorine in drinking water plants and, consequently, a decrease in the formation of carcinogenic disinfection by-products (e.g. trihalomethanes (Sohn et al., 2007)). Natural biofilms as compared to biofilms in treatment facilities are exposed to very dynamic conditions dependent on natural and anthropogenic factors (Battin et al., 2003). Several studies reported that the type and quantity of organic matter as well as hydrodynamic conditions may influence the abundance and composition of bacteria in stream ecosystems (Koetsier et al., 1997; Battin et al., 2003). So far, little is known about the effect of dynamic changes of hydrodynamics and carbon availability on the cell density and bacterial community composition of biofilms formed on HSs. Therefore, the aim of this study is to investigate the effects of flow velocity and carbon concentration of HSs on biofilm structure and microbial composition using a model biofilm flowcell (Rodrigues et al., 2008).

\section{Methods}

\subsection{Experimental system}

A biofilm flowcell system (Fig. 1) was designed to study biofilm formation with and without humic substances (HSs) under defined hydrodynamic conditions (Rodrigues et al., 2008). Briefly, the biofilm flowcell system contained a mixing chamber connected to a flowcell and the liquid phase was recirculated from the mixing chamber to the flowcell and back using a centrifugal pump. The recirculation flow provided by the centrifugal pump was maintained constant by means of a rotameter. Synthetic river water supplemented with HSs was continuously added to the mixing chamber at a constant flow rate of $0.25 \mathrm{~mL} \mathrm{~min}^{-1}$, using a peristaltic pump, and the mixing chamber was continuously aerated to provide aerobic conditions in the system. The dissolved oxygen in the system was around $7 \mathrm{mg} \mathrm{L}^{-1}$. The biofilm flowcell system was operated in the dark and the temperature was maintained at $20 \pm 1{ }^{\circ} \mathrm{C}$ by means of cold water circulation in the water jacket around the flowcell. The flowcell was made of polyacrylic material with $0.042 \mathrm{~m}$ inner diameter and $1.04 \mathrm{~m}$ length, corresponding to a total submerged area of $0.14 \mathrm{~m}^{2}$. Ten independently removable thermo-polypropylene coupons (Matala ${ }^{\mathrm{TM}}$, USA) with $0.072 \mathrm{~m}$ length, $0.025 \mathrm{~m}$ width and $0.010 \mathrm{~m}$ height in average were fitted in the cell, allowing for biofilm sampling. The specific surface area of the material was $204 \mathrm{~m}^{2} \mathrm{~m}^{-3}$, yielding an average surface of $2.74 \times 10^{-4} \mathrm{~m}^{2}$ per coupon.

\subsection{Experimental approach}

Synthetic river water was prepared as previously described (Rodrigues et al., 2008) and used in the experiments. The background carbon concentration of the synthetic river water was $1.3 \pm 0.8 \mathrm{mg} \mathrm{L}^{-1}$, resulting from the distilled water used in the preparation of all solutions. The synthetic river water was supplemented with a concentrated HSs solution and the final $\mathrm{pH}$ adjusted to $7.0 \pm 0.2$ with either $2 \mathrm{M} \mathrm{NaCl}$ or $\mathrm{HCl}$ solutions. HSs extracted from Elliot Silt Loam Soil (BS102M) were purchased from the International Humic Substances Society (IHSS, USA). A concentrated HSs stock solution ( $1 \mathrm{~g} \mathrm{~L}^{-1}$ carbon) was prepared and stored in the dark at $4{ }^{\circ} \mathrm{C}$.

Biofilms were previously formed during 10 weeks with $(9.7 \pm$ $1.0 \mathrm{mg} \mathrm{L}^{-1}$ of carbon) and without $\left(1.3 \pm 0.8 \mathrm{mg} \mathrm{L}^{-1}\right.$ of carbon, background carbon concentration in the distilled water) HSs, at a flow velocity of $0.04 \mathrm{~m} \mathrm{~s}^{-1}$ (Rodrigues et al., 2008). Three biofilm flowcell systems were run in parallel, two with HSs and one without. To study the biofilm's response to variations in flow velocity and HSs concentration, four experimental assays were carried out, as described in Table 1. All experiments were performed over a four weeks period. The biofilms response to an increase in HSs concentration from $9.7 \pm 1.0 \mathrm{mg} \mathrm{L}^{-1}$ to $19.8 \pm 0.4 \mathrm{mg} \mathrm{L}^{-1}$ of carbon and flow velocity from $0.04 \mathrm{~m} \mathrm{~s}^{-1}$ to $0.10 \mathrm{~m} \mathrm{~s}^{-1}$ was evaluated. The velocity was calculated as the ratio between the flow rate and the cross sectional area of the empty flowcell. An increase in flow velocity was achieved by manipulating the recirculation flow rate in the flowcell.

Table 1

Experimental conditions used in the flowcells to study the biofilm's response to changes in humic substances (HSs) concentration and flow velocity.

\begin{tabular}{clll}
\hline Biofilm & Mode of operation & & \\
\cline { 2 - 4 } & $\begin{array}{l}\text { Carbon concentration } \\
\left(\mathrm{mg} \mathrm{L}^{-1}\right)\end{array}$ & $\begin{array}{l}\text { Flow velocity } \\
\left(\mathrm{m} \mathrm{s}^{-1}\right)\end{array}$ & Flowcell \\
\hline $\begin{array}{c}\text { Without } \\
\text { HSs }\end{array}$ & $1.3 \pm 0.8$ & $0.04 \rightarrow 0.10$ & $\mathrm{~A}$ \\
With HSs & $9.7 \pm 1.0 \rightarrow 19.8 \pm 0.4$ & 0.04 & $\mathrm{~B}$ \\
& $9.7 \pm 1.0$ & $0.04 \rightarrow 0.10$ & $\mathrm{Ca}$ \\
& $9.7 \pm 1.0 \rightarrow 19.8 \pm 0.4$ & 0.10 & $\mathrm{Cb}$ \\
\hline
\end{tabular}

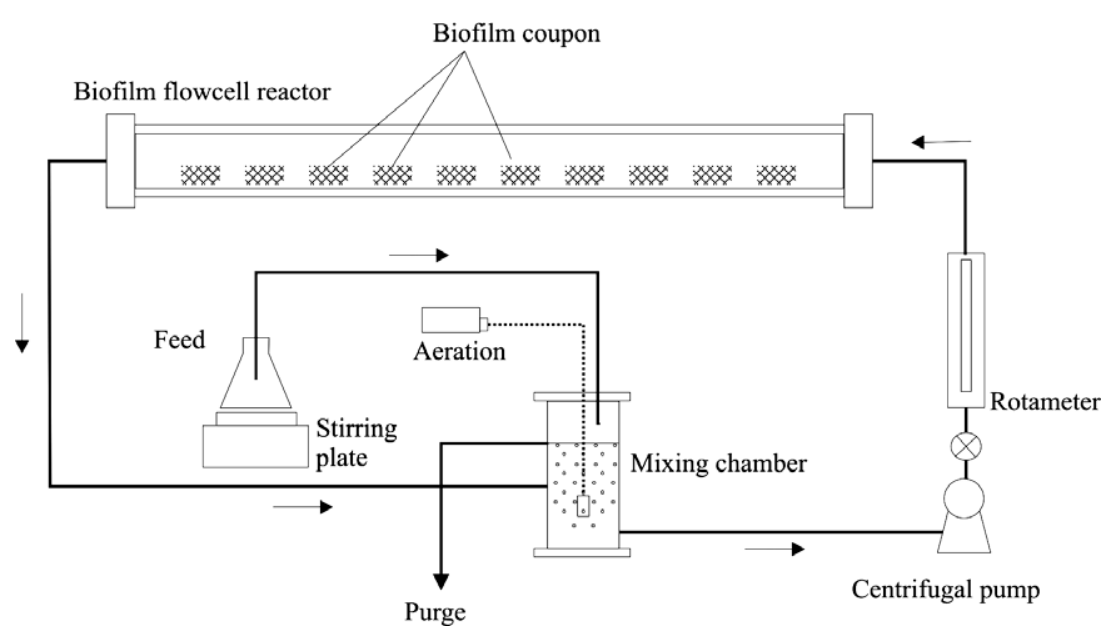

Fig. 1. Schematic of experimental set-up. 


\subsubsection{Biofilm's response to an increase in flow velocity}

The experiment was conducted in two subsequent steps. During the first one flowcells A and Ca were operated at a flow velocity of $0.04 \mathrm{~m} \mathrm{~s}^{-1} \quad\left(200 \mathrm{~L} \mathrm{~h}^{-1}, \quad \mathrm{Re}=1669\right)$ during 10 weeks without $\left(1.3 \pm 0.8 \mathrm{mg} \mathrm{L}^{-1}\right.$ of carbon) and with $\left(9.7 \pm 1.0 \mathrm{mg} \mathrm{L}^{-1}\right.$ of carbon) HSs, respectively (Rodrigues et al., 2008). Subsequently, the flow velocity in both biofilm flowcells was increased from $0.04 \mathrm{~m} \mathrm{~s}^{-1}$ to $0.10 \mathrm{~m} \mathrm{~s}^{-1}\left(499 \mathrm{~L} \mathrm{~h}^{-1}, \operatorname{Re}=4179\right)$, and maintained at this last value during four weeks.

\subsubsection{Biofilm's response to an increase in HSs concentration under low and high flow velocities}

During the first step of the experiment the flowcell B was operated at a flow velocity of $0.04 \mathrm{~m} \mathrm{~s}^{-1}$ during 10 weeks with HSs (9.7 $\pm 1.0 \mathrm{mg} \mathrm{L}^{-1}$ of carbon). Subsequently, the HSs concentration was increased from $9.7 \pm 1.0 \mathrm{mg} \mathrm{L}^{-1}$ to $19.8 \pm 0.4 \mathrm{mg} \mathrm{L}^{-1}$, and maintained at this last value during 4 weeks.

To evaluate the biofilm's response to an increase in HSs concentration at a flow velocity of $0.10 \mathrm{~m} \mathrm{~s}^{-1}$, a third experimental step was carried out using flowcell $\mathrm{Ca}$, whose experimental conditions are indicated in Table 1 under the denomination of flowcell $\mathrm{Cb}$. The HSs concentration was increased from $9.7 \pm 1.0 \mathrm{mg} \mathrm{L}^{-1}$ to $19.8 \pm 0.4 \mathrm{mg} \mathrm{L}^{-1}$, and maintained at this last value during four more weeks.

\subsection{Sampling}

Biofilm samples were collected weekly for volatile suspended solids (VSS) and total cell counts (TC). Measurements were made in duplicate. For DNA extraction biofilm samples were collected before and after each change in HSs concentration and flow velocity.

The biofilm in the flowcells was sampled by removing a coupon and placing it aseptically into a falcon tube containing $40 \mathrm{~mL}$ of sterile Ringer's solution (Gross and Berndt, 1992). The tube was vigorously vortexed for $5 \mathrm{~min}$, sonicated for $15 \mathrm{~min}$ in a sonication bath (Model SC-52, Sonicor, USA) and vortexed again for 5 min. Subsequently, the clean coupon was removed and the biofilm suspension was then homogenized for $20 \mathrm{~min}$ using a tissuemizer with SBS-dispensing tool (model AV 5, SBS, Spain).

\subsection{Analytical methods}

Total organic carbon was determined by the combustion-infrared method (Rodrigues et al., 2009) using a Shimadzu TOC-5000A analyzer (Labonal, Portugal). Biomass was quantified both as volatile suspended solids (VSS) and total countable cells (TC). VSS were measured according to the gravimetric method described in Standard Methods (APHA, AWWA, WPCF, 1998). Samples for TC, previously fixed with $40 \mathrm{~g} \mathrm{~L}^{-1}$ paraformaldehyde, were stained with 4,6diamino-2-phenylindole (DAPI) (VWR International, Portugal) (0.25 $\left.\mathrm{mg} \mathrm{L}^{-1}\right)$ for $15 \mathrm{~min}$, filtered onto a black-stained polycarbonate filter (Nucleopore) (VWR International, Portugal) with $2.27 \mathrm{~cm}^{2}$ of filtration surface area and, rinsed with $5 \mathrm{~mL}$ of sterilized distilled water. Cell enumeration was carried out in an epifluorescence microscope (Zeiss, Germany, filter set no. 01, excitation $\lambda=372$ $\mathrm{nm}$, emission $\lambda=456 \mathrm{~nm}$ ) at 1000 fold magnification, a total of 20 fields was evaluated using a graduated grid divided into 346 squares $\left(1 \times 10^{-6} \mathrm{~cm}^{2}\right.$ each square). The total surface area examined per sample was $1.8 \times 10^{-6} \mathrm{~cm}^{2}$ (20 fields times nine squares).

\subsection{Molecular characterization of biofilms bacterial community}

16S rRNA gene-targeting techniques, such as denaturing gradient gel electrophoresis (DGGE), cloning and, sequencing analysis were used as cultivation-independent tools for analysis of bacterial diversity in the biofilms.

\subsubsection{DNA extraction and amplification}

Approximately $2 \mathrm{~mL}$ of a well homogenized biofilm sample was frozen at the time of sampling and stored at $-20^{\circ} \mathrm{C}$. Total genomic DNA was extracted using a UltraClean ${ }^{\mathrm{TM}}$ Soil DNA Isolation Kit (MO BIO, Carlsbad, CA, USA) according to the protocol described by the manufacturer.

The 16S rRNA genes were amplified by polymerase chain reaction (PCR) using a Taq DNA Polymerase (Invitrogen, Carlsbad, CA, USA) with primers targeting conserved domains. PCR amplification was performed in a $50 \mu \mathrm{L}$ reaction mixture containing $5 \mu \mathrm{L}$ of $10 \mathrm{X}$ PCR buffer (20 mM Tris- $\mathrm{HCl}$ (pH 8.4), $500 \mathrm{mM} \mathrm{KCl}$ ), $3 \mathrm{mM} \mathrm{MgCl}$, $200 \mu \mathrm{M}$ of each of the four deoxynucleoside triphosphates (dNTP) (Invitrogen, Carlsbad, CA, USA), $1.25 \mathrm{U}$ of Taq polymerase, $200 \mathrm{nM}$ of each primer and $1 \mu \mathrm{L}$ of appropriately diluted template DNA. All primers used were synthesized by STAB Vida (Oeiras, Portugal). For DGGE analysis the 16S rRNA gene fragments were amplified using suitable bacterial primers U968-GC-f (5'-CGCCCGCCGCGCGCGGCGGG CGGGGCGGGGGCACGGGGGGAACGCGAAGAACCTTAC-3') and L 1401-r (5'-CGGTGTGTACAAGACCC-3'), targeting the V6-V8 region (Nübel et al., 1996). The thermocycling program used for amplification was: an initial denaturation step of $5 \mathrm{~min}$ at $95^{\circ} \mathrm{C}$; 35 cycles of denaturation at $95{ }^{\circ} \mathrm{C}$ for $30 \mathrm{~s}$, annealing at $56^{\circ} \mathrm{C}$ for $40 \mathrm{~s}$ and, elongation at $72{ }^{\circ} \mathrm{C}$ for $90 \mathrm{~s}$; and post-elongation at $72{ }^{\circ} \mathrm{C}$ for $5 \mathrm{~min}$. The reactions were subsequently cooled to $4{ }^{\circ} \mathrm{C}$. The 16S rRNA gene fragments were also amplified for cloning using the forward primer Bact27-f (5'-AGAGTTTGATCMTGGCTCAG-3') and the universal primer Uni1492-r (5'-ACGCCTACCTTGTTACGACTT-3') (Heuer et al., 1997). The program of amplification was similar to the one described above but with 25 cycles and an annealing temperature of $52{ }^{\circ} \mathrm{C}$. A negative control (no DNA added) was included in all sets of amplification. The size of the PCR products was estimated using a 100 bp DNA ladder (Frilabo, Porto, Portugal) by electrophoresis in a $1 \%(\mathrm{wt} / \mathrm{vol})$ agarose gel stained with ethidium bromide (VWR International, Portugal).

\subsubsection{DGGE analysis}

Denaturing gradient gel electrophoresis analysis of the amplicons was carried out using the Dcode system (Bio-Rad, Hercules, CA, USA) in gels containing $8 \%(\mathrm{w} / \mathrm{vol})$ polyacrylamide $(37.5: 1$ acrylamide/bis-acrylamide). Denaturating gels were generated using a gradient mixer and a peristaltic pump by standard procedures. The gradient was made at an approximate rate of $4 \mathrm{~mL} \mathrm{~min}{ }^{-1}$. A linear denaturant gradient of $30-60 \%$ was used for all analyses, where a denaturing strength solution of $100 \%$ was defined as $7 \mathrm{M}$ urea (Sigma-Aldrich, St. Louis, MO, USA) and 40\% formamide (Fluka Chemie, Buchs, Switzerland). Gels were run for $16 \mathrm{~h}$ at $85 \mathrm{~V}$ in a $0.5 \mathrm{X}$ TAE buffer (50X Tris acetate: $242 \mathrm{~g}$ Tris, $57.1 \mathrm{~mL}$ glacial acetic acid, $100 \mathrm{~mL} 0.5 \mathrm{M}$ EDTA ( $\mathrm{pH}$ 8.0) per liter) at $60^{\circ} \mathrm{C}$. Subsequently, DGGE gels were stained with silver as previously described by Sanguinetty et al. (1994). DGGE profiles were compared using the Bionumerics 5.0 software package (Applied Maths, Belgium) in terms of similarity indices, that were calculated from the scanned DGGE profiles using Dice's coefficients. This coefficient ranges from $0 \%$ (no common bands) to 100\% (identical bands patterns). Cluster analysis was conducted for band matching with $1 \%$ position tolerance and the unweighted pair group method with arithmetic means (UPGMA).

\subsubsection{Cloning and sequencing of PCR amplified products}

PCR amplicons were purified with the QIAquick PCR purification kit (Qiagen $\mathrm{GmbH}$, Hilden, Germany) and cloned into Escherichia coli JM 109 (Invitrogen, Carlsbad, CA, USA) using the Promega pGEM-T Easy vector system I (Promega, Madison, WI, USA), accord- 
ing to the manufacturer's instructions. The transformed cells were plated onto LB (Luria-Bertani) medium (10 g of bacto-triptone, $5 \mathrm{~g}$ of bacto-yeast extract, $5 \mathrm{~g}$ of $\mathrm{NaCl}, 15 \mathrm{~g}$ Bacto agar, $\mathrm{pH} 7.0)$ containing ampicillin $\left(100 \mu \mathrm{g} \mathrm{mL}^{-1}\right)$, X-Gal (5-bromo-4chloro-3-indolyl- $\beta$-D-galactoside: $80 \mu \mathrm{g} \mathrm{mL}^{-1}$ ) and, IPTG (Isopropyl $\beta$-D-1-thiogalactopyranoside: $0.5 \mathrm{mM}$ ) to identify white-colored recombinant colonies, all these products were purchased from the Sigma-Aldrich, St. Louis, MO, USA. 50 white-colored clones were collected and screened by DGGE. PCR was carried out on the cell lysates using the primer pair above described for DGGE analysis. The DGGE mobility of amplicons was compared to the bandpattern of the biofilm. The clones whose amplicon's corresponded to bands in the biofilm community profile were selected for sequencing. Clones with sequences showing identical DGGE mobility were also selected for replicate sequencing. Plasmids of selected clones were purified using the QIAquick PCR purification kit (Qiagen GmbH, Hilden, Germany) and subjected to DNA sequence analysis. Sequencing reactions were performed at STAB Vida using SP6 (5'-ATT TAG GTG ACA CTA TAG-3') and T7 (5'-TAA TAC GAC TCA CTA TAG G-3') sequencing primers. The sequence information was imported into the BioEdit v7.0.9 software package for assembly. Consensus sequences obtained were manually checked and corrected when necessary. They were also checked for potential chimera artefacts by the CHECK_CHIMERA program of the Ribosomal Database Project II (http://35.8.164.52/cgis/chimera. cgi?su=SSU). Similarity searches for the $16 \mathrm{~S}$ rRNA gene sequences derived from the biofilm clones were performed using the NCBI Blast search program within the GenBank database (http:// www.ncbi.nlm.nih.gov/blast/).

Sequence data of the 16S rRNA genes have been deposited in the GenBank database under accession numbers GU169052GU169067.

\subsection{Statistical analyses}

A $t$-test was used where specific means were compared. Acceptance or rejection of the null hypothesis was based on a $\alpha$-level of 0.05 in all cases.

\section{Results and discussion}

\subsection{Effects of flow velocity and HSs concentration on biofilms}

This study was designed to investigate the response of biofilms to an increase in HSs concentration and flow velocity. Biofilms were previously formed during 10 weeks with HSs $\left(9.7 \pm 1.0 \mathrm{mg} \mathrm{L}^{-1}\right.$ of carbon) and without $\left(1.3 \pm 0.8 \mathrm{mg} \mathrm{L}^{-1}\right.$ of carbon) HSs, at a flow velocity of $0.04 \mathrm{~m} \mathrm{~s}^{-1}$ (Rodrigues et al., 2008). The composition of biofilms formed under these conditions was characterized by a VSS content of $36.1 \pm 1.7 \mathrm{~g} \mathrm{~m}^{-2}$ with HSs (flowcell Ca) and $34.3 \pm 1.7 \mathrm{~g} \mathrm{~m}^{-2}$ without HSs (flowcell A). The TC content of both biofilms was $1.2 \times 10^{12} \pm 1.0 \times 10^{11}$ cell m ${ }^{-2}$ with HSs and $1.610^{12} \pm 1.2 \times 10^{11}$ cell $\mathrm{m}^{-2}$ without HSs. The VSS and TC content of both biofilms were very similar in spite of the different concentrations of soluble organic carbon in solution. Therefore, soluble organic carbon from HSs and distilled water might have not been equally bioavailable.

Fig. 2, panels I and II, shows the VSS and TC per square meter in biofilms with HSs (flowcell Ca) and without (flowcell A) HSs. The flow velocity in both biofilm flowcells was increased from 0.04 $\mathrm{m} \mathrm{s}^{-1}$ to $0.10 \mathrm{~m} \mathrm{~s}^{-1}$, at time zero, and maintained at this last value during 4 weeks. These results revealed that flow velocity had no significant effect on the VSS content in the biofilm with HSs (flowcell Ca); VSS varied from $36.1 \pm 1.7 \mathrm{~g} \mathrm{~m}^{-2}$ to $33.9 \pm 1.7 \mathrm{~g} \mathrm{~m}^{-2}$ after 4 weeks. Conversely, the VSS content in the biofilm without HSs (flowcell A) increased significantly from $34.3 \pm 1.7 \mathrm{~g} \mathrm{~m}^{-2}$ to $89.7 \pm 5.1 \mathrm{~g} \mathrm{~m}^{-2}$ (by ca. $62 \%$ ). Regarding the TC content, both biofilms were significantly impacted by velocity but the effect was considerably higher in the biofilm without HSs. The TC content of the biofilm without HSs increased by ca. $55 \%$ in 4 weeks (from $1.4 \times 10^{12} \pm 0.2 \times 10^{11}$ cell m$^{-2}$ to $3.2 \times 10^{12} \pm 0.9 \times 10^{11}$ cell $\mathrm{m}^{-2}$ ), whereas in the biofilm with HSs a smaller increase was observed, by ca. $25 \%$ (from $1.2 \times 10^{12} \pm 1.0 \times 10^{11}$ cell m$^{-2}$ to $1.6 \times$ $10^{12} \pm 1.2 \cdot 10^{11}$ cell $^{-2}$ ). These results suggested that the impact of velocity in the composition of biofilms is positive and higher in the biofilm without HSs. The explanation presented for these results is that the availability of organic carbon (growth limiting substrate) in the biofilm with and without HSs increased due to a lower mass transfer resistance in the liquid film boundary layer on top of the biofilm occurring at higher flow velocities; nevertheless, this effect was probably overcome in the case of the biofilm with HSs by an inhibitory effect that HSs yielded to the biofilm. Previous experiments demonstrated that HSs form complexes with enzymes in the biofilm matrix reducing its hydrolytic activity and consequently the biofilm growth (Boavida and Wetzel, 2002; McNamara and Leff, 2004).

Fig. 3, panels I and II, shows the response of biofilms under low $\left(0.04 \mathrm{~m} \mathrm{~s}^{-1}\right.$, flowcell B) and high $\left(0.10 \mathrm{~m} \mathrm{~s}^{-1}\right.$, flowcell $\left.\mathrm{Cb}\right)$ flow velocities to an increase in HSs concentration from $9.7 \pm 1.0 \mathrm{mg} \mathrm{L}^{-1}$ to $19.3 \pm 0.4 \mathrm{mg} \mathrm{L}^{-1}$ of carbon, at time zero, and maintained at this last value during 4 weeks. Although VSS content of both biofilms might have not reached steady-state after 4 weeks, these results suggested that the VSS content of the biofilm at $0.04 \mathrm{~m} \mathrm{~s}^{-1}$ slightly increased, based on initial and final values (from $26.4 \pm 2.9 \mathrm{mg} \mathrm{L}^{-1}$ to $31.3 \pm 1.0 \mathrm{mg} \mathrm{L}^{-1}$ ), whereas an opposite trend was observed in the case of the biofilm at $0.10 \mathrm{~m} \mathrm{~s}^{-1}$ (from $33.9 \pm 1.7 \mathrm{mg} \mathrm{L}^{-1}$ to $21.4 \pm 0.3 \mathrm{mg} \mathrm{L}^{-1}$ ). The TC content of the biofilm presented a similar trend. The combined effect of HSs concentration and flow rate, expressed as a mass flow rate, on biofilm's SSV and TC is depicted
I

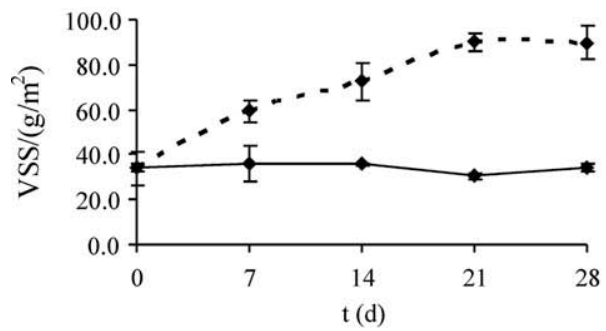

II $\quad-\uparrow$ Flowcell A

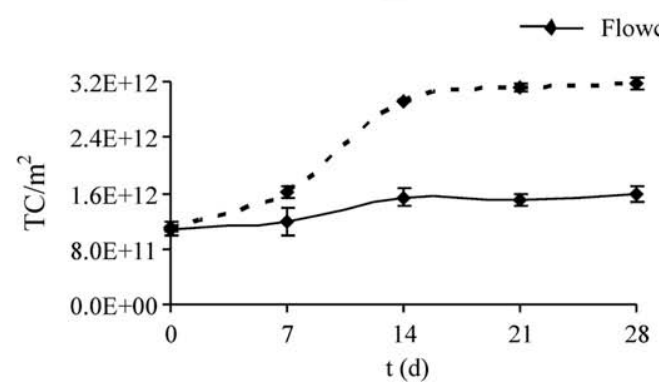

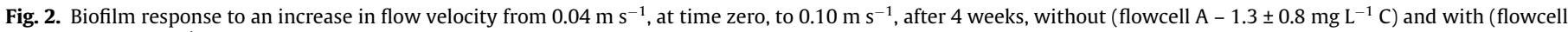
$\mathrm{Ca}-9.7 \pm 1.0 \mathrm{mg} \mathrm{L}^{-1} \mathrm{C}$ ) HSs. Volatile suspended solids (VSS) and total cells (TC) per square meter are presented in panels I and II, respectively. 

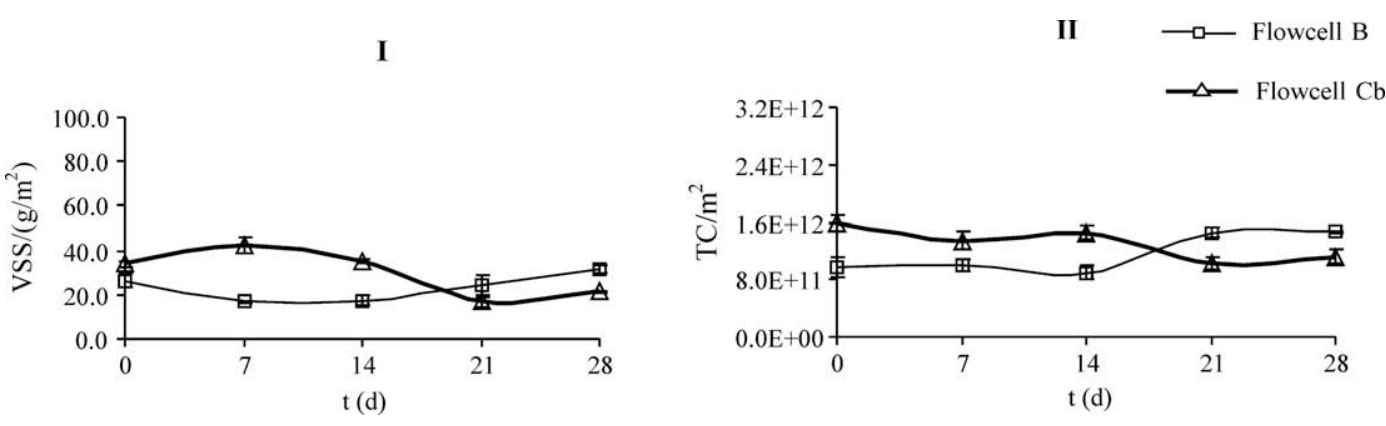

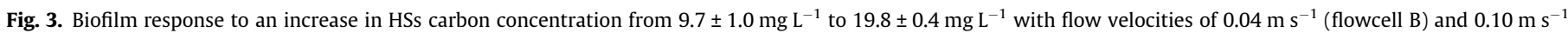
(flowcell Cb). Volatile suspended solids (VSS) and total cells (TC) per square meter are presented in panels I and II, respectively.

in Fig. 4. The results suggested that the biofilm VSS and TC contents increased with an increase in the HSs mass flow from $2 \mathrm{~g} \mathrm{~h}^{-1}$ to $5 \mathrm{~g} \mathrm{~h}^{-1}$. The highest amount of biofilm was observed at a flow velocity of $0.10 \mathrm{~m} \mathrm{~s}^{-1}$ and a HSs concentration of $9.7 \mathrm{mg} \mathrm{L}^{-1}$. Doubling the mass flow rate from $5 \mathrm{~g} \mathrm{~h}^{-1}$ to $10 \mathrm{~g} \mathrm{~h}^{-1}$ produced a decrease of both VSS and TC in the biofilm. This result might be associated to the increase in the HSs concentration from $9.7 \mathrm{mg} \mathrm{L}^{-1}$ to $19.8 \mathrm{mg} \mathrm{L}^{-1}$ because flow velocity was maintained at $0.10 \mathrm{~m} \mathrm{~s}^{-1}$. As suggested previously in this study, HSs might have inhibited biofilm growth at high HSs concentrations.

\subsection{Effects of flow velocity and HSs concentration on biofilms bacterial community structure}

The study of diversity and dynamics of bacteria in biofilms was based on DGGE patterns of partial 16S rRNA gene amplicons. DNA extracted from biofilms collected from each flowcell (A, B, Ca and $\mathrm{Cb})$, at the beginning and end of each operation period, was used as template for amplification of the V6-V8 bacterial region. These amplicons were separated by DGGE and the obtained band-patterns are depicted in Fig. 5, panel I. Apart from changes in the relative intensity of a few bands, DGGE band-patterns of biofilms exposed to different flow velocities and carbon concentrations did not differ significantly from the initial ones (time 0 ), as reveled by the obtained similarity indeces $\left(A_{0} / A_{4}-90.9 \%, B_{0} / B_{4}-81.6 \%, \mathrm{Ca}_{0} /\right.$ $\mathrm{Ca}_{4}-88.4 \%$ and $\mathrm{Ca}_{0} / \mathrm{Cb}_{4}-85.7 \%$ (Fig. 5, panel II)). In the biofilm without HSs, a significant increase in the relative intensity of ribotypes represented by bands $A b 1$ and $A b 2$ was observed when the flow velocity was changed from $0.04 \mathrm{~m} \mathrm{~s}^{-1}\left(\mathrm{~A}_{0}\right)$ to $0.10 \mathrm{~m} \mathrm{~s}^{-1}\left(\mathrm{~A}_{4}\right)$, suggesting a positive effect of flow velocity in the predominance of these ribotypes. Regarding the biofilm with humic substances, it was observed an apparent decrease of the relative predominance (in terms of intensity) of band P4 in the DGGE profile $\mathrm{B}_{4}$

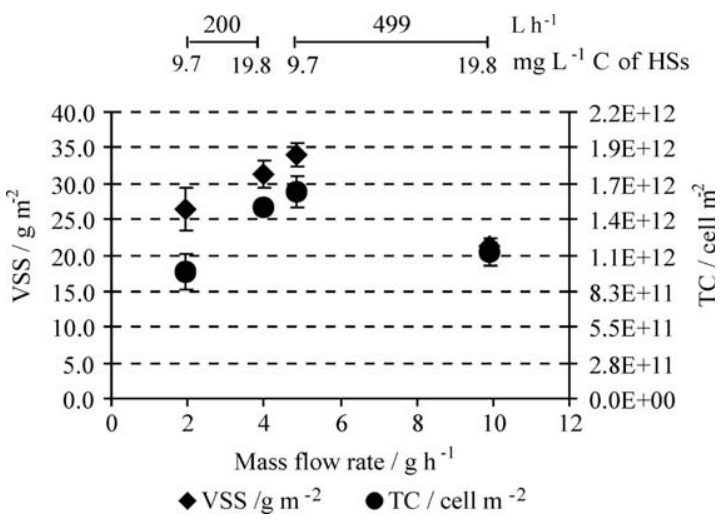

Fig. 4. Biofilm response to an increase in HSs mass flow rate.
(19.8 $\left.\pm 0.4 \mathrm{mg} \mathrm{L}^{-1} \mathrm{C}\right)$ when comparing to $\mathrm{B}_{0}\left(9.7 \pm 1.0 \mathrm{mg} \mathrm{L}^{-1} \mathrm{C}\right)$, suggesting that increasing the concentration of HSs had a negative effect in the dominance of the ribotype represented by this band. UPGMA cluster analysis using Dice's coefficient showed two clearly different clusters in DGGE similarity, biofilms with $\left(\mathrm{B}_{0}, \mathrm{Ca}_{0}, \mathrm{~B}_{4}, \mathrm{Ca}_{4}\right.$, $\left.\mathrm{Cb}_{4}\right)$ and without $\left(\mathrm{A}_{0}, \mathrm{~A}_{4}\right)$ HSs (Fig. 5 , panel II), suggesting that the presence or absence of HSs had an influence in the developed bacterial community.

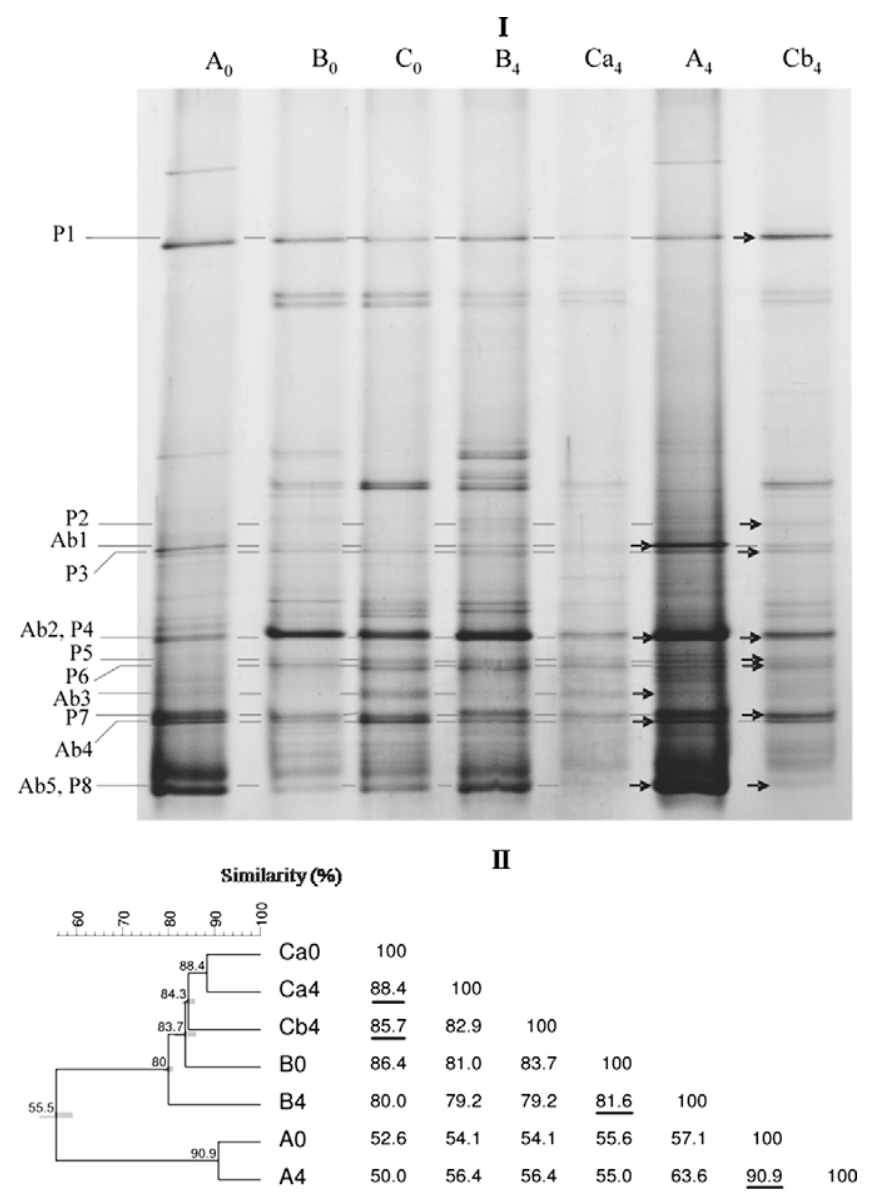

Fig. 5. (I) DGGE patterns of bacterial communities in biofilms without $\left(A_{0}, A_{4}\right)$ and with $\left(\mathrm{B}_{0}, \mathrm{Ca}_{0}, \mathrm{~B}_{4}, \mathrm{Ca}_{4}, \mathrm{Cb}_{4}\right)$ HSs under different hydrodynamic conditions and carbon concentrations: $A_{4}$ - after flow velocity increase of $A_{0}, B_{4}$ - after carbon concentration increase of $\mathrm{B}_{0}, \mathrm{Ca}_{4}$ - after flow velocity increase of $\mathrm{Ca}_{0}, \mathrm{Cb}_{4}$ - after flow velocity and carbon concentration increase of $\mathrm{Ca}_{0}$. Annotated DGGE bands were further identified by cloning and sequencing. (II) Corresponding similarity index dendrogram (UPGMA clustering) and similarity matrix (calculated with Dice's similarity coefficients). 
To get an insight into the identity of the bacterial community represented in the DGGE patterns, 16S rRNA genes of two representative biofilm samples without $\left(\mathrm{A}_{4}\right)$ and with $\left(\mathrm{Cb}_{4}\right)$ HSs were amplified, cloned and sequenced. The DGGE mobility of amplicons obtained from a total of 100 clones was compared to DGGE profiles of both biofilms to determine the fragments to which they match. A total of 16 clones were selected from both biofilms without (Ab1-Ab7) and with (P1-P9) HSs. Clones Ab1, Ab2, Ab4 and Ab5 presented bands that corresponded to the prominent ones (i.e., higher signal intensity) in the DGGE profile of the biofilm without HSs $\left(\mathrm{A}_{4}\right)$ and clones P1, P4 and P7 corresponded to the prominent bands in the DGGE profile of the biofilm with $\mathrm{HSs}\left(\mathrm{Cb}_{4}\right)$ (Fig. 5, panel I). Clones Ab6, Ab7 and P9 did not match any visible bands. These clones may represent bacterial ribotypes present in lower number, or with lower PCR amplification efficiency, that did not form visible bands in the DGGE patterns but were randomly picked out by cloning. Sequencing and blast searching of the selected bacterial clones resulted mainly in matches with unknown and uncultured microorganisms assigned to the Proteobacteria (clones Ab1, Ab2, Ab3, Ab4, Ab7, P2, P4, P5, P6, P7), Deinococcus-Thermus group (clones Ab5, P8) and, Acidobacteria (P1). In addition, close relatives to Sphingomonas sp. (clone Ab6) belonging to the alpha subclass of Proteobacteria and close relatives to Comamonas sp. (clone P3) and Cupriavidus pauculus (clone P9) belonging to the beta subclass of the same group, were also found. The sequencing results are summarised in Table 2.

In the following paragraph the phylogenetic analysis of the sequences corresponding to prominent ribotypes in the DGGE profiles is going to be discussed. Clones Ab2 and P4 presented

Table 2

Sequencing results of the clones of biofilms formed without and with humic substances (HSs).

\begin{tabular}{|c|c|c|c|}
\hline Clone & $\begin{array}{l}\text { GenBank } \\
\text { accession } \\
\text { number }\end{array}$ & $\begin{array}{l}\text { Sequence } \\
\text { length } \\
\text { (bp) }\end{array}$ & $\begin{array}{l}\text { Closest relatives (\% sequence } \\
\text { similarity) }\end{array}$ \\
\hline Abl & GU169052 & 1462 & Bacterium Ellin339 (99\%) \\
\hline Ab2 & GU169053 & 1470 & $\begin{array}{l}\text { Uncultured bacterium clone FAC50 } \\
\text { (98\%), Gamma Proteobacterium KIS3-4 } \\
(98 \%)\end{array}$ \\
\hline Ab3 & GU169054 & 1464 & $\begin{array}{l}\text { Uncultured ammonia-oxidizing } \\
\text { bacterium (98\%), Nitrosospira sp. } \\
\text { Nsp65 (98\%) }\end{array}$ \\
\hline Ab4 & GU169055 & 1460 & $\begin{array}{l}\text { Uncultured ammonia-oxidizing } \\
\text { bacterium (99\%), Nitrosospira sp. } \\
\text { Nsp65 (99\%) }\end{array}$ \\
\hline Ab5 & GU169056 & 1415 & $\begin{array}{l}\text { Uncultured Thermaceae bacterium } \\
\text { clone HAVOmatl } 18 \text { (93\%), } \\
\text { Meiothermus cerbereus GY-5 (91\%) }\end{array}$ \\
\hline Ab6 & GU169057 & 1411 & Sphingomonas sp. MG49 (99\%) \\
\hline Ab7 & GU169058 & 1405 & $\begin{array}{l}\text { Uncultured bacterium clone 3BH-11EE } \\
\text { (97\%), Caulobacter sp. (95\%) }\end{array}$ \\
\hline PI & GU169059 & 1466 & $\begin{array}{l}\text { Uncultured bacterium clone 3BH-6HH } \\
\text { (94\%), Geothrix fermentans ( } 94 \%)\end{array}$ \\
\hline P2 & GU169060 & 1462 & Bacterium Ellin307 (98\%) \\
\hline P3 & GU169061 & 1446 & Comamonas sp. PND-3 (97\%) \\
\hline P4 & GU169062 & 1469 & $\begin{array}{l}\text { Uncultured bacterium clone FAC50 } \\
\text { (99\%), Gamma Proteobacterium KIS3-4 } \\
(99 \%)\end{array}$ \\
\hline P5 & GU169063 & 1463 & $\begin{array}{l}\text { Uncultured Ralstonia sp. clone GI6-1- } \\
\text { F10 (99\%), Ralstonia sp. EF1 (99\%) }\end{array}$ \\
\hline P6 & GU169064 & 1461 & $\begin{array}{l}\text { Uncultured bacterium clone Pia-s-4 } \\
\text { (97\%), Denitrifying bacterium W99 } \\
(97 \%)\end{array}$ \\
\hline P7 & GU169065 & 1473 & $\begin{array}{l}\text { Uncultured bacterium clone KD5-12 } \\
\text { (97\%), Dokdonella sp. KIS28-6 (97\%) }\end{array}$ \\
\hline P8 & GU169066 & 1416 & $\begin{array}{l}\text { Uncultured Thermaceae bacterium } \\
\text { clone HAVOmatl } 18 \text { (93\%), } \\
\text { Meiothermus cerbereus (90\%) }\end{array}$ \\
\hline P9 & GU169067 & 1457 & Cupriavidus pauculus (98\%) \\
\hline
\end{tabular}

similar band positions. Their sequences were most similar to those of yet uncultured microorganisms assigned to the gamma subclass of Proteobacteria. Several studies reported that members of the gamma-Proteobacteria did not constitute a dominant phylogenetic group in stream biofilms (Brümmer et al., 2000; Araya et al., 2003); however, Pohlon et al. (2010) observed an enrichment of gammaProteobacteria population in later stages of biofilm formation. Clones P7 was related to Dokdonella sp. and clone Ab4 to Nitrosospira sp., which belong to different subclasses of Proteobacteria, namely gamma-Proteobacteria and beta-Proteobacteria, respectively. Dokdonella-like bacteria were isolated from soil (Cunha et al., 2006), but its environmental function is not yet fully investigated. The ammonia-oxidizing bacteria of the genus Nitrosospira are abundant in freshwater ecosystems, and are involved in the nitrogen cycle, oxidizing ammonium to nitrite (Kowalchuk and Stephen, 2001). Clones Ab5 and P8 presented similar band positions and show very low similarity to sequences deposited in the GenBank database. Clone Ab1 was affiliated to subclass gammaProteobacteria and closely related to Ellin339, a soil bacterium isolated from polychlorinated biphenyls contaminated-soil (Sait et al., 2002).

Additional sequences retrieved only from biofilms formed without HSs were related to subclass alpha-Proteobacteria, namely to Sphingomonas (clone Ab6) and Caulobacteraceae family (clone Ab7), and to subclass beta-Proteobacteria, specifically to Nitrosospira genus (clones $\mathrm{Ab} 3$ and $\mathrm{Ab} 4)$. Caulobacter spp. live in fresh water lakes and streams and play an important role in the carbon cycle, having the ability to metabolize organic materials available in low quantities (Staley et al., 1987; Brun and Janakiraman, 2000). The widespread distribution of Sphingomonas in the environment is due to its ability to utilize a wide range of organic compounds including refractory contaminants (White et al., 1996). Other sequences retrieved only from biofilms with HSs were related to subclass beta-Proteobacteria, namely to Comamonas (clone P3), Ralstonia (clone P5) and Cupriavidus (clone P9) genera, and to gamma-Proteobacteria, namely to bacterium Ellin337 (clone P2) and Dokdonella genus (clone P7). Bacteria of the genus Comamonas have been isolated from soil contaminated with polynuclear aromatic hydrocarbons, and bacteria of the genus Cupriavidus and Ralstonia have been isolated from metal-contaminated soils (Vacca et al., 2005; Chen et al., 2008). A common feature of these bacteria is that they are capable of interacting with humic acids that are the most prevalent form of organic matter is soils. In the present study, it was to be expected that bacteria growing in the biofilm would be able to cope with the presence of HSs, but the function of these microbial groups remains relatively unknown. This uncertainty is related to the source of organic matter that was used for biofilm growth, humic substances, the background organic carbon present in the synthetic river water, or both.

The different sequences retrieved from biofilms with and without HSs can not assure different bacteria diversity, however the DGGE profiles of both samples indicate different bacterial population's dominance in biofilms formed in the presence and absence of HSs. Phylogenetic analysis of the sequences corresponding to prominent ribotypes in the DGGE profiles suggested that the prevalent groups of bacteria present in both biofilms formed with and without HSs are related to bacteria known to thrive in terrestrial and aquatic environments sparse in organic compounds.

The results obtained in this work showed a higher microbial diversity (measured as mumber of bands) than the observed in the previous work (Rodrigues et al., 2008). The differences observed might be due to three main reasons: (i) different methods (culture-dependent and culture-independent) were used to assess bacterial phylogenetic diversity and from literature it is known that culture-independent methods revealed greater microbial diversity than culture-dependent ones (Ward et al., 1990); (ii) flow 
velocity and concentration of NOM were different and might have influenced biofilm composition (Koetsier et al., 1997; Besemer et al., 2007); (iii) biofilms had different ages.

\section{Conclusions}

From this study it can be suggested that HSs concentration had no significant impact on biofilm cell density under different flow velocities but HS presence influenced biofilm microbial composition. The bacterial community composition of the biofilm with HSs was characterized by sequences with high similarities $(\geqslant 97 \%)$ to the genus Dokdonella (gamma-Proteobacteria) and to the genera Comamonas, Cupriavidus and, Ralstonia (beta-Proteobacteria) while sequences retrieved from the biofilm without HSs presented high similarities ( $\geqslant 97 \%$ ) to the genus Sphingomonas (alphaProteobacteria) and the genus Nitrosospira (beta-Proteobacteria).

\section{Acknowledgements}

The work described in this paper was financially supported by FCT - Foundation for Science and Technology (Portugal) - by the PhD student Grant SFRH/BD/18565/2004. This support is gratefully acknowledged.

\section{References}

Amann, R.I., Ludwig, W., Schleifer, K.H., 1995. Phylogenetic identification and in situ detection of individual microbial cells without cultivation. Microbiol. Rev. 59, 143-169.

APHA, AWWA, WPCF, 1998. Standard Methods for the Examination of Water and Wastewater, 20th ed. American Public Health Association (Ed.), Washington, DC, USA.

Araya, R., Tatsuya, T., Nobuyasu, Y., Masao, N., 2003. Bacterial activity and community composition in stream water and biofilm from an urban river determined by fluorescent in situ hybridization and DGGE analysis. FEMS Microbiol. Ecol. 43, 111-119.

Battin, T.J., Kaplan, L.A., Newbold, J.D., Hansen, C., 2003. Contributions of microbial biofilms to ecosystem processes in stream mesocosms. Nature 426, 439-442.

Beckett, R., 1990. The surface chemistry of humic substances in aquatic systems. In: Beckett, R. (Ed.), Surface and Colloid Chemistry in Natural Waters and Water Treatment. Plenum, New York, NY, pp. 3-16.

Besemer, K., Singer, G., Limberger, R., Chlup, A.-K., Hochedlinger, G., Hödl, I., Baranyi, C., Battin, T.J., 2007. Biophysical controls on community succession in stream biofilms. Appl. Environ. Microbiol. 73, 4966-4974.

Boavida, M.-J., Wetzel, R.G., 2002. Inhibition of phosphatase activity by dissolved humic substances and hydrolytic reactivation by natural ultraviolet light. Freshwater Biol. 40, 285-293.

Brümmer, I.H.M., Felske, A., Wagner-Döbler, I., 2003. Diversity and seasonal variability of $\beta$-Proteobacteria in biofilms of polluted rivers: analysis by temperature gradient gel electrophoresis and cloning. Appl. Environ. Microbiol. 69, 4463-4473.

Brun, Y.V., Janakiraman, R., 2000. The dimorphic life cycle of Caulobacter and stalked bacteria. In: Brun, Y.V., Shimkets, L.J. (Eds.), Prokaryotic Development. American Society for Microbiology, Washington, DC, pp. 297-317.

Bryers, J.D., Characklis, W.G., 1982. Processes governing primary biofilm formation. Biotechnol. Bioeng. 24, 2451-2476.

Chen, W.-M., Wu, C.-H., James, E.K., Chang, J.-S., 2008. Metal biosorption capability of Cupriavidus taiwanensis and its effects on heavy metal removal by nodulated Mimosa pudica. J. Hazard. Mater. 151, 364-371.
Cunha, S., Tiago, I., Pires, A.L., da Costa, M.S., Veríssimo, A., 2006. Dokdonella fugitiva sp. nov., a Gammaproteobacterium isolated from potting soil. Syst. Appl. Microbiol. 29, 191-196.

Fang, H.H.P., Liang, D., Zhang, T., 2007. Aerobic degradation of diethyl phthalate by Sphingomonas sp.. Bioresour. Technol. 98, 717-720.

Gross, K.A., Berndt, C.C., 1992. In-vitro testing of plasma-sprayed hydroxyapatite coatings. J. Mater. Sci. Mater. Med. 5, 1-6.

Heuer, H., Krsek, M., Baker, P., Smalla, K., Wellington, E.M.H., 1997. Analysis of communities by specific amplification of genes encoding 16S rRNA and gelelectrophoretic separation in denaturing gradients. Appl. Environ. Microbiol. 63, 3233-3241.

Kim, S., Kaplan, L.A., Hatcher, P.G., 2006. Biodegradable dissolved organic matter in a temperate and a tropical stream determined from ultra-high resolution mass spectrometry. Limnol. Oceanogr. 51, 1054-1063.

Koetsier, P., McArthur, V., Leff, L.G., 1997. Spatial and temporal response of stream bacteria to sources of dissolved organic carbon in a blackwater system. Freshwater Biol. 37, 79-89.

Kowalchuk, G.A., Stephen, J.R., 2001. Ammonia-oxidizing bacteria: a model for molecular microbial ecology. Annu. Rev. Microbiol. 55, 485-529.

Lawrence, J.R., Neu, T.R., 2003. Microscale analyses of the formation and nature of microbial biofilm communities in river systems. Rev. Environ. Sci. Biotechnol. 2 85-97.

Lin, C.-F., Liu, S.-H., Hao, O.J., 2001. Effect of functional groups of humic substances on UF performance. Water Res. 35, 2395-2402.

McNamara, C.J., Leff, L.G., 2004. Response of biofilm bacteria to dissolved organic matter from decomposing maple leaves. Microbial Ecol. 48, 324-330.

Nübel, U., Engelen, B., Felske, A., Snaidr, J., Wieshuber, A., Amann, R.I., Ludwig, W., Backhaus, H., 1996. Sequence heterogeneities of genes encoding 16S rRNA in Paenibacillus polymyxa detected by temperature gradient gel electrophoresis. J. Bacteriol. 178, 5636-5643.

Olapade, O.A., Leff, L.G., 2005. Seasonal response of stream biofilm communities to dissolved organic matter and nutrient enrichments. Appl. Environ. Microbiol. 71, 2278-2287.

Peterson, H., 2008. The power of biology in drinking water treatment. A biological treatment process for better water and improved working conditions. Can Water Treat., 18-20.

Pinhassi, J., Berman, T., 2003. Differential growth response of colony-forming $\alpha$ - and $\gamma$-Proteobacteria in dilution culture and nutrient addition experiments from lake Kinneret (Israel), the eastern Mediterranean Sea, and the Gulf of Eilat. Appl. Environ. Microbiol. 69, 199-211.

Pohlon, E., Marxsen, J., Küsel, K., 2010. Pioneering bacterial and algal communities and potential extracellular enzyme activities of stream biofilms. FEMS Microbiol. Ecol. 71, 364-373.

Rodrigues, A.L., Brito, A.G., Janknecht, P., Silva, J., Machado, A.V., Nogueira, R., 2008 Characterization of biofilm formation on a humic material. J. Ind. Microbiol. Biotechnol. 35, 1269-1276.

Rodrigues, A.L., Brito, A.G., Janknecht, P., Proença, M.F., Nogueira, R., 2009 Quantification of humic acids in surface water: effects of divalent cations, $\mathrm{pH}$, and filtration. J. Environ. Monit. 11, 377-382.

Sait, M., Hugenholtz, P., Janssen, P.H., 2002. Cultivation of globally distributed soil bacteria from phylogenetic lineages previously only detected in cultivationindependent surveys. Environ. Microbiol. 4, 654-666.

Sanguinetty, C.J., Dias Neto, E., Simpson, A.J.G., 1994. Rapid silver staining and recovery of PCR products on acrylamide gels. Biotechniques 17, 915-919.

Sohn, J., Amy, G., Yeomin, Y., 2007. Process-train profiles of NOM through a drinking water treatment plant. J. AWWA 99, 145-153.

Staley, J.T., Konopka, A.E., Dalmasso, J.P., 1987. Spatial and temporal distribution of Caulobacter spp. in two mesotrophic lakes. FEMS Microbiol. Lett. 45, 1-6.

Tank, J.L., Dodds, W.K., 2003. Nutrient limitation of epilithic and epixylic biofilms in ten North American streams. Freshwater Biol. 48, 1031-1049.

Vacca, D.J., Bleam, W.F., Hickey, W.J., 2005. Isolation of soil bacteria adapted to degrade humic acid-sorbed phenanthrene. Appl. Environ. Microbiol. 71, 37973805 .

Ward, D.M., Weller, R., Bateson, M.M., 1990. 16S rRNA sequences reveal numerous uncultivated microorganisms in a natural environment. Nature 345, 63-65.

Wetzel, R.G., 2001. Limnology. Lake and River Ecosystems, third ed. Academic Press, San Diego, CA.

White, D.C., Suttont, S.D., Ringelberg, D.B., 1996. The genus Sphingomonas: physiology and ecology. Curr. Opin. Biotechnol. 7, 301-306. 